\title{
Fen Bilimleri Öğretmenlerinin Beceri Kavramına Yönelik Algıları: Bir Olgubilim Çalışması
}

\author{
Ersin KARADEMIR, Emine SARIKAHYA, Kübra ALTUNSOY*
}

Fen Bilimleri Öğretmenlerinin Beceri Kavramına Yönelik Algıları: Bir Olgubilim Çalışması

Özet

Bu çalışmanın amacı, fen bilimleri dersini yürütmekte olan öğretmenlerin beceri kavramı hakkındaki algılarının ortaya çıkarıımasıdır. Bu amaç doğrultusunda fen bilimleri öğretmenlerinin beceri hakkındaki kavramsal bilgileri, becerileri sınfflandırmaları, mesleki anlamda kullanım durumları, öğretim programındaki yeri hakkındaki görüşleri, yetenek-zekâ ilişkisi ve ölçülebilirliği hakkındaki görüşlerinin ortaya çıkarılmasına çalışılmıştır. Bu çalışmada nitel araştırma yöntemlerinden olan olgubilim (fenomenoloji) deseni kullanıımışı̆. Bu çalışmada, fen bilimleri dersini yürütmekte olan öğretmenlerin "beceriye yönelik algı" olgusu detaylı bir şekilde incelenmeye çalışılmıştır. Çalışma grubu ölçüt örnekleme yoluyla belirlenmiş, çalışma grubunda yer alacak, beceri kavramı hakkındaki görüşlerine göre 15 öğretmen çalışmaya dahil edilmiştir. Araştırmada veri toplama aracı olarak görüşme tekniği kullanılmıştır. Öğretmenlere yöneltilen beceriler hakkındaki sorulardan elde edilen verilerin analizi sonucunda öğretmen görüşleri bağlamında altı farklı kategori altında toplanmıştır.

Anahtar Kelimeler: Beceri, Fen Bilimleri Öğretmeni, Olgubilim, Öğretmen Görüşleri.
The Perceptions of the Science Teachers toward to the Concept of Skill: A Phenomenological Study

\section{Abstract}

The purpose of this study is to reveal the perceptions of the teachers about the concept of skill. It was tried to find out the conceptual information about science teachers' skills, classifications of skills, occupational use situations, opinions about the place in the curriculum, talent-intelligence relation and measurability. In this study, phenomenology method is used and it was attempted to examine in detail the "perception of the skill" of the teachers who are carrying out the science course. The study group was determined by sampling and included in the study group 15 teachers. It is aimed at reflecting the experiences of the people who are the subject of the research. Interview technique was used as data collection tool. As a result of the analysis the opinions of the teachers were collected under six different categories in the context of the questions in the interview form.

Key Words: Skill, Science Teacher, Phenomenology, Teachers'views.

\section{Giriş}

Bilimin gelişimi insanoğlunun doğuştan merakını gidermek için belirli bir bakış açısı ile karmaşık doğal fenomenleri ve durumları sorgulamasının sonucudur. Bu sayede toplumlar zekâlarını kullana-

*Ersin KARADEMiR, Yrd.Doç.Dr., Eskişehir Osmangazi Üniversitesi, Eğitim Fakültesi,eekarademir@gmail.com; Emine SARIKAHYA, Yük.Lis.Öğr., Eskişehir Osmangazi Üniversitesi, Eğitim Bilimleri Enstitüsü,e.sarikahya@gmail.com; Kübra ALTUNSOY, Yük.Lis.Öğr., Eskişehir Osmangazi Üniversitesi, Eğitim Bilimleri Enstitüsü,kubraleb@hotmail.com 
rak ve düşünme ile akıl yürütme becerisini uygulayarak bilimsel bilgilerini yapılandırmışlardır. Bu durum eski dönemlerde bile bilim bir düşünme yönteminin gerçekten bir ürünü olduğunu göstermektedir (Joseph, 1998). Birçok farklı ülke fen eğitiminde bilimsel süreçlere verdiği önemi göstermek için eğitim programlarının idealleri içerisinde yer vermektedir [Ministry of Singapor, 2007; Korean Ministry of Education, Science and Technology, 2008; The Courses of Study in Japan, 2004; Finnish National Board of Education, 2004]. Bilimsel süreç belirli bir amaç ya da ürünü elde etmek için gerçekleştirilen etkinlik ya da işlemler dizisidir. Bilimsel süreçler evrenin keşfedilmesi sürecinde nitelikli bir insan tarafından yürütülen, birbiriyle ilişkili etkinlikleri içine alır. Bu beceriler öğrencilerin feni öğrenmesi sonucu olarak elde edilen bilimsel inceleme için ihtiyaç duyulan zihinsel becerilerdir (Joseph, 1998).

Genel anlamda beceri tanımını incelediğimizde; öğrencilerde, öğrenme süreci içerisinde kazanılması, geliştirilmesi ve yaşama aktarılması tasarlanan kabiliyetlerdir (KKTCMEB, 2009). Farklı disiplinler bağlamında ele alındığında beceriler; eleştirel düşünme becerisi, yaratıcı düşünme becerisi, iletişim becerisi, araştırma becerisi, problem çözme becerisi, bilgi teknolojilerini kullanma becerisi, girişimcilik becerisi, Türkçeyi doğru, güzel ve etkili kullanma becerisi vb. şekilde kategorilere ayrılabilir (KKTC MEB, 2005). Söz konusu becerilerin olabildiğince fazlası çağdaş bireyde bulunması gerekli özelliklerdendir. Yaşamsal faaliyetlerini etkili bir biçimde gerçekleştirmek isteyen bireyin bu becerilerle donanmış olarak yetiştirilmesi gerekmektedir (Semerci ve Yanpar Yelken, 2010).

Bilgiyi yapılandırma ve ürüne dönüştürme aşamalarında kullanılan beceri ise bilimsel süreç becerileridir. Bilimsel bilgiyi üretme, kullanma ve problem çözme faaliyetleri için bilimsel süreç becerileri önemli bir araçtır. Bu becerilere sadece bilim insanları değil toplumun her kesiminin sahip olması gereklidir (Aktamış ve Şahin Pekmez, 2011). Ülkemizde geliştirilen fen öğretimi programlarında da öğrencilerin bilimsel süreç becerilerini kazandırılması programın ana hedeflerindendir. 2006 yılında yapılan programda bilimsel süreç becerilerine yer verilirken, 2013 yılında revize edilen programda beceri öğrenme alanı başlığında toplanmış ve yaşam becerileri eklenmiştir (M.E.B., 2006; 2013).

Bilimsel süreç becerilerine ilişkin literatür incelendiğinde öğrencilerin aşama aşama kazanması gereken alt becerilerden bahsedilmiş ve tanımlamaları yapılmıştır (Harlen, 1999; Bernstein, 2003; Chin, 2003; Kurz, 2001; Timmons, 2003; Jimarez, 2005; Bozkurt, 2005; Erdoğan, 2005; Tatar, 2006; Kanlı, 2007). Bunlar sırasıyla (1) gözlemleme, (2) sınıflandırma, (3) çıkarımda bulunma, (4) bilgiyi paylaşma, (5) ölçme, (6) sayıları kullanma, (7) tahmin etme, (8) veriyi yorumlama, (9) değişkenleri kontrol etme, (10) hipotez kurma, (11) deney tasarlama ve (12) işlemsel tanım yapmadır. Öğretim programları içerisinde bu alt becerilerin özellikle 1-4 arasında okul öncesi dönemden ikinci sınıfa kadar; 5-6 arasındaki beceriler ise birinci sınıf ile dördüncü sınıf arasında; 7-10 arasındaki beceriler, üçüncü ve altıncı sınıf düzeyleri arasında; 11-12 alt beceriler ise beşinci ve altıncı sınıf düzeyindeki öğrencilerin kazanması gerektiği üzerine büyük önem verilmektedir (Pardhan, 2000).

Tablo 1'de görüldüğü üzere; bilimsel süreç becerileri; beceri öğrenme alanı altında, yaşam becerileri alt alanı ile birlikte açıklanmıştır. Bilimsel Süreç Becerileri; gözlem yapma, ölçme, sınıflama, verileri 
kaydetme, hipotez kurma, verileri kullanma ve model oluşturma, değişkenleri değiştirme ve kontrol etme, deney yapma gibi bilim insanlarının çalışmaları sırasında kullandıkları becerileri kapsarken; yaşam Becerileri; bilimsel bilgiye ulaşılması ve bilimsel bilginin kullanılmasına ilişkin analitik düşünme, karar verme, yaratıcılık, girişimcilik, iletişim ve takım çalışması gibi temel yaşam becerilerini kapsamaktadır (MEB, 2013).

Tablo 1. Öğrencilere fen bilimleri öğretim programı ile kazandırılacak olan beceriler

\begin{tabular}{|c|c|c|}
\hline \multirow{3}{*}{ 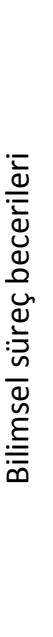 } & Planlama ve Başlama & $\begin{array}{l}\text { Gözlem } \\
\text { Karşılaştırma-sınıflama } \\
\text { Çıkarım yapma } \\
\text { Tahmin } \\
\text { Kestirme } \\
\text { Değişkenleri belirleme }\end{array}$ \\
\hline & Yapma & $\begin{array}{l}\text { Deney tasarlama } \\
\text { Deney malzemelerini ve araç-gereçlerini } \\
\text { tanıma ve kullanma } \\
\text { Bilgi ve veri toplama } \\
\text { Ölçme } \\
\text { Verileri kaydetme }\end{array}$ \\
\hline & Analiz ve Sonuç çıkarma & $\begin{array}{l}\text { Veri işleme ve model oluşturma } \\
\text { Yorumlama ve sonuç çıkarma } \\
\text { Sunma }\end{array}$ \\
\hline 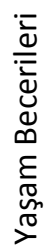 & $\begin{array}{l}\text { Analitik düşünme } \\
\text { Karar verme } \\
\text { Yaratıcılık } \\
\text { Girişimcilik } \\
\text { Iletişim } \\
\text { Takım calıșması }\end{array}$ & \\
\hline
\end{tabular}

Öğretmenlerin sahip oldukları beceriler, öğrencilere kazandırılacak beceriler üzerinde son derece etkilidir (Yayla ve Hançer, 2011). Öğretmenlerin mesleki yeterlilikleri, alan becerileri ve fen okuryazarı bireyler yetiştirmeye verdikleri önem, öğrencilere bilimsel süreç becerileri ile yaşam becerileri kazandırmada büyük rol oynamaktadır. Bu nedenle öğretmenlerin bu kavramlar hakkındaki görüşlerinin belirlenmesinin eğitim öğretim alanına katkı sağlayacağı düşünülmektedir. Bu çalışmanın amacı, fen bilimleri dersine yürütmekte olan öğretmenlerin beceri kavramı hakkındaki algılarının ortaya çıkarılmasıdır. Bu amaç doğrultusunda fen bilimleri öğretmenlerinin beceri hakkındaki kavramsal bilgileri, becerileri sınıflandırmaları, mesleki anlamda kullanım durumları, öğretim programındaki yeri hakkındaki görüşleri, yetenek-zekâ ilişkisi ve ölçülebilirliği hakkındaki görüşlerinin ortaya çıkarılmasına çalışılmıştır. 


\section{Yöntem}

\subsection{Model}

Bu çalışmada nitel araştırma yöntemlerinden olan olgubilim (fenomenoloji) deseni kullanılmıştır. Olgubilim deseni fark ettiğimiz, ancak derin ve detaylı bir anlayışa sahip olmadığımız olgulara odaklanmaktadır. Bir araştırma bir veya birkaç kişinin deneyimlerine ilişkin hikayeleri rapor ederken, fenomenolojik çalışma birkaç kişinin bir fenomen veya kavramlarla ilgili yaşanmış deneyimlerinin ortak anlamını tanımlar (Özet, 2014). Olgubilim çalışmalarının temel amacı, bir olguyla ilgili kişisel deneyimleri, daha genel bir düzeye çekmektir (Creswell, 2007). Olgubilim çalışmalarında genellikle bir olguya ilişkin bireysel algıların ortaya çıkarılması ve yorumlanması amaçlanır (Yıldırım ve Şimşek, 2008). Bu çalışmada, fen bilimleri dersini yürütmekte olan öğretmenlerin "beceriye yönelik algı" olgusu detaylı bir şekilde incelenmeye çalışılımıştır.

\section{2. Çalışma Grubu}

Olgubilim çalışmalarında olguyu (fenomeni) bütün yönleriyle deneyim etmiş bir grup birey ile çalışarak bu fenomen araştırıır. Bu yüzden, büyüklüğü 3-4 kişi ile 10-15 kişi arasında değişen heterojen bir grup belirlenir (Özet, 2014). Fenomenolojik modelde desenlenen araştırmanın çalışma grubu, fen bilimleri öğretmenlerin beceri kavramına ilişkin görüşlerini belirlemeyi amaçladığı için amaçlı örnekleme yöntemi ile seçilen öğretmenlerden oluşmaktadır. Araştırmanın çalışma grubu, amaçlı örnekleme yönteminden biri olan ölçüt örnekleme ile seçilmiştir. Bir araştırmada gözlem birimleri belli niteliklere sahip kişiler, olaylar, nesneler ya da durumlardan oluşturulabilir. Bu duruma örneklem için belirlenen ölçütü karşılayan birimler (nesneler, olaylar vb.) örnekleme alınırlar (Büyüköztürk vd., 2008). Çalışma grubu ölçüt örnekleme yoluyla belirlenmiş, çalışma grubunda yer alacak, beceri kavramı hakkındaki görüşlerine göre 15 öğretmen çalışmaya dahil edilmiştir. Bu sayede, araştırmaya konu olan olguyu yaşayan kişilerin deneyimlerinin yansıtılması amaçlanmıştır. Bu çalışmada katıımcıların belirlenmesinde; fen bilimleri dersi öğretmeni olma temel ölçüt olarak dikkate alınmıştır. Buna göre araştırmaya, farklı mesleki kıdemlere sahip fen bilimleri öğretmenleri katılmıştır. Araştırmaya katılan fen bilimleri dersi öğretmenleri ile ilgili özellikler Tablo 2'de verilmiştir.

Tablo 2. Öğretmenlerin demografik özellikleri

\begin{tabular}{|c|c|c|c|c|}
\hline Öğretmen & Cinsiyet & Kıdem Yılı & $\begin{array}{l}\text { Mezun Olunan Fakülte/ } \\
\text { Bölüm }\end{array}$ & $\begin{array}{l}\text { Lisansüstü Ĕ̆i- } \\
\text { tim Durumu }\end{array}$ \\
\hline Ö1 & Erkek & $0-5$ yıl & $\begin{array}{l}\text { Fen Bilgisi-Matematik Öğ- } \\
\text { retmenliği }\end{array}$ & Yapıyor \\
\hline Ö2 & Kadın & $0-5$ yıl & Fen Bilgisi Öğretmenliği & Yapıyor \\
\hline Ö3 & Kadın & $0-5$ yıl & Fen Bilgisi Öğretmenliği & Yapmadı \\
\hline Ö4 & Kadın & $0-5$ yıl & Fen Bilgisi Öğretmenliği & Yapmadı \\
\hline Ö5 & Kadın & $0-5$ yıl & Fen Bilgisi Öğretmenliği & Yapıyor \\
\hline Ö6 & Kadın & $0-5$ yıl & Fen Bilgisi Öğretmenliği & Yapmadı \\
\hline
\end{tabular}


Eskişehir Osmangazi Üniversitesi Sosyal Bilimler Dergisi

\begin{tabular}{lllll}
\hline Ö7 & Kadın & $11-20$ yıl & Fen bilgisi Öğretmenliği & Yüksek lisans \\
Ö8 & Kadın & $11-20$ yıl & Fen Bilgisi Öğretmenliği & Yüksek Lisans \\
Ö9 & Kadın & $11-20$ yıl & Fen Bilgisi Öğretmenliği & Yapmadı \\
Ö10 & Erkek & $11-20$ yıl & Fen Bilgisi Öğretmenliği & Yapmadı \\
Ö11 & Erkek & $11-20$ yıl & Fen Bilgisi Öğretmenliği & Yapmadı \\
Ö12 & Kadın & 21 yıl ve üzeri & Kimya Öğretmenliği & Yapmadı \\
Ö13 & Kadın & 21 yıl ve üzeri & Biyoloji & Yapmadı \\
Ö14 & Erkek & 21 yıl ve üzeri & Fen Bilgisi Öğretmenliği & Yapmadı \\
Ö15 & Kadın & 21 yıl ve üzeri & Fen fakültesi / Kimya bö- & Yapmadı \\
& & & lümü & \\
\hline
\end{tabular}

\subsection{Veri Toplama Araçları}

Olgubilim çalışmalarında genellikle veri toplama aracı olarak görüşme kullanılır (Yıldırım \& Şimşek, 2008). Araştırma fenomenoloji desenine dayalı olarak gerçekleştirildiğinden veri toplama aracı olarak görüşme tekniği kullanılmıştır. Olgulara ilişkin deneyim ve anlamları ortaya çıkarmada görüşme tekniği araştırmacılara etkileşim, esneklik ve sondalar yoluyla irdeleme olanakları sunar (Yıldırım ve Şimşek, 2008). Yarı yapılandııımış görüşme formu oluşturulurken ilgili alanyazın ayrıntılı olarak taranmış ve öğretmenlerin beceri kavramıyla ilgili algılarını saptamak amacı ile çeşitli maddeler belirlenerek uzman görüşüne başvurulmuştur. Fen eğitimi alanında iki öğretim üyesi, üç fen bilimleri öğretmeni olmak üzere toplam beş ilgili alandaki uzmanların incelemeleri sonucunda " fen bilimleri öğretmenlerinin beceriye yönelik algıları" görüşme formunda yer alan sorular uzman görüşleri sonucunda yeniden düzenlenmiş, eksik bulunan maddeler eklenerek ve maddeler üzerinde düzenlemeler yapıldıktan sonra araştırmanın amacına uygun, anlaşılır ve uygulanabilir olduğu ortaya konmuştur. Üç fen bilimleri öğretmeni ile yapılan ön uygulama sonucunda görüşme formunun uygun olduğu görülmüştür. Görüşme formunda; öğretmenlerin genel anlamda beceri kavramı hakkındaki görüşleri, beceri odaklı etkinlikler yapıp yapmadıkları, beceri ile zeka-yetenek ilişkisi, fen bilimleri öğretim programında yer alan beceri alanına dair görüşleri, becerilerin sınıflandırılması, ulusal sınavlarda ve derslerinde becerinin ölçülebilirliği ile ilgili sorular yer almaktadır (Bkz: Ek.1).

\subsection{Verilerin Çözümlenmesi}

Olgubilim (fenomenoloji) desenini kullanan çalışmaların amacı, insanların belli bir olgu (fenomen) ya da gerçeğin belirli bir yönünü kavrama, onunla ilgili yorumda bulunma ya da anlamlandırmada kullandıkları farklı yolları aramaktır. Bu arayışla beraber olgular üzerinde anlamlar ortaya çıkarılır ve bu anlamlar kategorilere göre sınıflandırılır (Çepni, 2010). Bu çalışmada görüşmeler yoluyla elde edilen veriler, içerik analizi yaklaşımıyla çözümlenmiştir. İçerik analizinde yapılan temel işlem, birbirine benzeyen verileri belirli kavramlar ve temalar çerçevesinde bir araya getirmek ve bunları okuyucunun anlayabileceği şekilde düzenleyerek yorumlamaktır (Yıldırım ve Şimşek, 2006).

Araştırmada, her bir soruya verilen yanıtların dökümü yapılmıştır. Verilerin dökümünden sonra, veri analiz çerçevesi olarak görüşmede sorulan soru bağlamlarının kullanılmasına karar verilmiştir. Yani temalar oluşturulurken, görüşme soruları bağlamında yapılmış, öğretmenlerden gelen 
cevaplardan yola çıkarak birbiri ile ilişkili ya da benzer sorular aynı temalarda birleştirilmiştir. Cevap seçeneklerinin güvenirliliğini belirlemek için üçer öğretmenin görüşme dökümü yansız atama yöntemiyle seçilmiştir. Seçilen üç öğretmen dökümü kodlama ile birlikte uzmanlara verilmiştir. Araştırmacı ve uzmanlar, bağımsız olarak, görüşme yapılan görüşlerle ilgili kodlamaya işaretleyerek görüş belirtmişlerdir. İçerik analizi ile ortaya çıkan kategoriler, doğrudan alıntılarla da desteklenmiştir.

\subsection{Geçerlik ve Güvenirlik}

Alan uzmanından, aynı temaları dışarıda tema kalmayacak şekilde kavramsal kategorilerle karşılaştırması istenmiştir. Uzmanın yapmış olduğu karşılaştırmalar araştırmacıların yapmış olduğu karşılaştırmalar ile tutarılığı kontrol edilmiştir. Karşılaştırmalarda görüş birliği ve görüş ayrılığı sayıları tespit edilerek araştırmanın güvenirliği Miles \& Huberman "ın (1994) Güvenirlik=görüş birliği/(görüş birliği+görüş ayrılı̆̆ı) formülü kullanılarak hesaplanmıştır. Yazarlara göre \% 90 ve üzeri olduğu durumlarda istenen güvenirlik sağlanacağı düşünülmüş ve bu çalışmada \% 91 oranında bir uzlaşma (güvenirlik) sağlanmış olması çalışmanın güvenirliği açısından yeterli görülebilir.

\section{Bulgular ve Yorum}

Öğretmenlere yöneltilen beceriler hakkındaki sorulardan elde edilen verilerin analizi sonucunda öğretmen görüşleri Şekil 1'de yer alan altı farklı kategori altında toplanmıştır. Söz konusu kategoriler görüşme formunda yer alan sorular bağlamında oluşturulmuştur. 


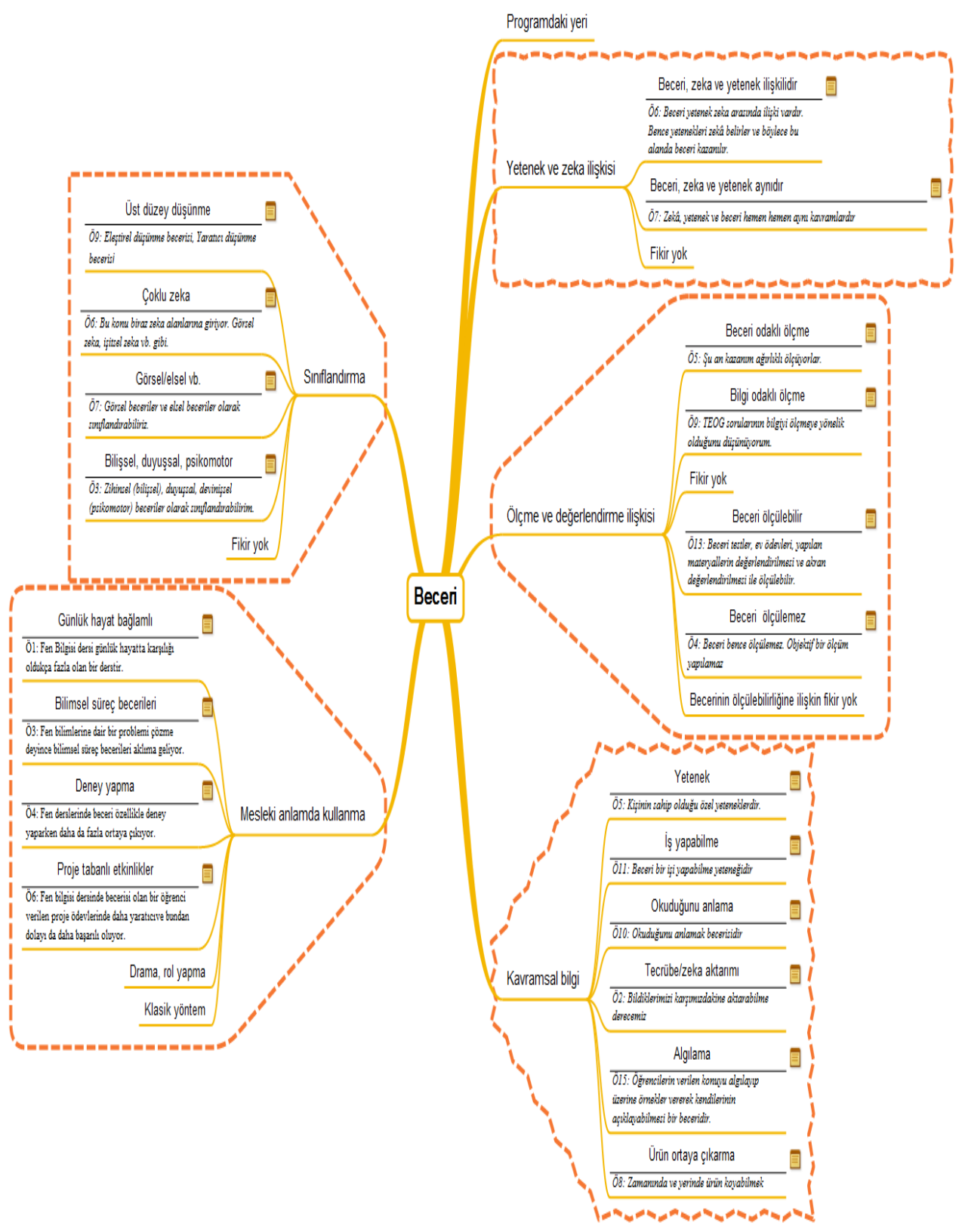

Şekil 1. Becerilere ait bulguların tema ve kategorilere ayrılması 


\section{1. Öğretmenlerin beceri kavramı hakkındaki görüşleri kategorisine ait bulgular:}

Öğretmenlere beceri hakkındaki fikirleri alınmıştır. Öğretmenlerin verdikleri cevaplar temalara ayrılmış ve Tablo 3' de sıklık tablosu belirtilmiştir.

Tablo 3. Beceri kavramına yönelik görüşler

\begin{tabular}{lll}
\hline \hline Görüşler & $f$ & Örnek \\
\hline Yetenek & 4 & Ö5: Kişinin sahip olduğu özel yeteneklerdir. \\
İş yapabilme & 3 & Ö11: Beceri bir işi yapabilme yeteneğidir. \\
Okuduğunu anlama & 1 & Ö10: Okuduğunu anlamak becerisidir \\
Tecrübe-zeka-aktarma & 2 & Ö2: Bildiklerimizi karşımızdakine aktarabilme derecemiz \\
Algılama & 2 & Ö15: Öğrencilerin verilen konuyu algılayıp üzerine örnekler ve- \\
Ürün ortaya çıkarma süreci & 2 & Ö8: Zamanında ve yerinde ürün koyabilmek \\
\hline
\end{tabular}

Tablo 3'de görüldüğü üzere öğretmenler beri kavramını açıklarken dört öğretmen (Ö1, Ö3, Ö5 ve Ö7) yetenek, üç öğretmen (Ö6, Ö9 ve Ö11) iş yapabilme eğilimi, iki öğretmen (Ö14 ve Ö15) algılama, iki öğretmen (Ö4 veÖ8) ürün ortaya çıkarma süreci, iki öğretmen (Ö2 ve Ö13) tecrübe ve zekanın aktarımı, bir öğretmen de (Ö10) okuduğunu anlama kavramlarını kullanmışlardır. Öğretmenlerin hiçbiri ortaokul fen bilimleri öğretim programında yer alan bilimsel süreç becerileri ve yaşam becerileri kavramlarını herhangi bir şekilde kullanmamışlardır. Mesleki kıdemleri az veya yüksek olması beceri kavramı hakkındaki görüşlerin fen bağlamında olmasına etki etmemiştir. Örneğin bir öğretmen; "Bence Beceri kişinin tecrübelerinin ve zekâsının birleşimiyle ortaya koyduğu ürünlerdir. Beceri kişinin tekrarlayan tecrübeleriyle kazanılıp geliştirilebileceği gibi zekâsının gereği de elde edebileceği bilgi veya ürünün kalitesidir." şeklinde bir görüş belirtmiş ve zekânın ürün oluşturma sürecindeki etkisinden bahsetmiştir.

\section{2. Öğretmenlerin becerinin sınıflandırılması hakkındaki görüşlerine ait bulgular:}

Literatürde birçok beceri sınıflandırması yer almaktadır. Fen bilimleri dersi öğretmenlerinin becerilerin sınıflandıııması hakkında görüşlerinin alınması sonucunda öğretim programı bağlamlı sınıflandırma yapmaları beklenmektedir. Öğretmenlerin becerileri nasıl sınıflandırdıklarına ait görüşleri alınmış ve ortaya çıkan temalar Tablo 4'de belirtilmiştir. 
Tablo 4. Becerinin sınıflandırılmasına yönelik görüşler

\begin{tabular}{lcl}
\hline \hline Görüşler & $f$ & Örnek \\
\hline Üst düzey düşünme & 4 & $\begin{array}{l}\text { Ö9: Eleştirel düşünme becerisi, Yaratıcı dü- } \\
\text { şünme becerisi }\end{array}$ \\
Çoklu zeka (zeka alanlarına göre) & 3 & $\begin{array}{l}\text { Ö6: Bu konu biraz zeka alanlarına giriyor. Görsel } \\
\text { zeka, işitsel zeka vb. gibi. }\end{array}$ \\
Görsel-elsel vb. olarak & 3 & $\begin{array}{l}\text { Ö7: Görsel beceriler ve elsel beceriler olarak sı- } \\
\text { nıflandırabiliriz. }\end{array}$ \\
Bilişsel, duyuşsal, psikomotor & 2 & $\begin{array}{l}\text { Ö3: Zihinsel (bilişsel), duyuşsal, devinişsel (psi- } \\
\text { komotor) beceriler olarak sınılandırabilirim. }\end{array}$ \\
Fikir yok & 4 & -
\end{tabular}

Tablo 4'de de görüldüğü üzere hiçbir öğretmen fen bilimleri dersi öğretim programında yer alan haliyle becerilere ait bir sınıflama gerçekleştirmemiştir. Tablo 3'de belirtildiği üzere; dört öğretmen (Ö1, Ö2, Ö5 ve Ö9) becerileri eleştirel düşünme-yaratıcı düşünme vb. gibi üst düzey düşünme becerileri olarak, üç öğretmen (Ö6, Ö8 ve Ö11) beceriyi çoklu zeka kuramı bağlamında, üç öğretmen (Ö7, Ö14 ve Ö15) beceriyi görsel-el vb. beceriler olarak, iki öğretmen (Ö3 veÖ8) beceriyi bilişsel-duyuşsalpsikomotor bağlamında sınıflandırmıştır. Bir öğretmen fen bilimleri ile ilişkili sınıflandırma yaparken şu şekilde bir açıklama ortaya çıkmıştır: "Zihinsel (bilişsel), duyuşsal, devinişsel (psikomotor) beceriler olarak sınıflandırabilirim. Öğretim programında 3 beceri alanı da vardır. Fen bilimlerine karşı olumlu tutum geliştirme duyuşsal beceri, teorik bilgileri öğrenmek zihinsel (bilişsel) süreç becerilerine girerken deney yapmak, ortaya ürün çıkarmak devinişsel becerilerdir." Söz konusu açıklama yanlış olmamakla beraber beklenen düzeyde değildir. "Bu konu biraz zeka alanlarına giriyor. Görsel zeka, işitsel zeka vb. gibi. Yine bu konuda öğrencilerim arasında çok farklılılar var. Benim dersimde başarısız olan bir öğrenci, Türkçe dersinde başarılı olabiliyor. Bu belki derse olan ilgisiyle alakalı, belki de Türkçe ve fen dersleri arasındaki sayısal ve sözel yetenekle ilgili olabilir. Ben de öğrencilerime dersime yönelik ekstra ödevler verirken, bu zeka alanlarına dikkat etmeye çalışıorum ve çok olumlu sonuçlar alıyorum." şeklinde açıklama yapan bir öğretmen zeka kavramı ile beceri kavramını birbirine yerine kullanarak kavramsal bir hata yapmıştır. Ayrıca dört öğretmen de becerilerin sınıflandırılması ile ilgili herhangi bir fikir beyan etmemiştir.

“Ö2: Beceriler, bilişsel, psikomotor ve de duyuşsal alanda olabilir. Örneğin öğrencinin öğrendiği bir konu hakkında şiir yazabilmesi, deney tasarlayabilmesi, sunum hazırlayabilmesi, o olayı canlandırabilmesi gibi. Mesela, Güneş, Dünya ve Ay'ın birbirine göre konumlarını hareketlerini verdiğim yönergeleri uygun şekilde karşılık verebilmesi ya da su ve iki mendil kullanarak buharlaşmanın her sıcaklıkta olduğunu gösteren bir deney tasarlaması." görüşünü belirten öğretmen becerileri fen programı bağlamında değil Bloom taksonomisi bağlamında sınıflandırmıştır. 
Ersin KARADEMIR | Emine SARIKAHYA | Kübra ALTUNSOY

\section{3. Öğretmenlerin mesleki olarak beceri odaklı etkinlik süreçleri ile ilgili görüşlerine ait bulgular}

Tablo 5. Mesleki olarak beceri odaklı etkinlik süreçleri ile ilgili görüşleri

\begin{tabular}{|c|c|c|}
\hline Görüşler & ff* $^{*}$ & Ö̈nek \\
\hline Günlük hayat bağlamlı & 4 & $\begin{array}{l}\text { Ö1: Fen Bilgisi dersi günlük hayatta karşılığı oldukça fazla } \\
\text { olan bir derstir. }\end{array}$ \\
\hline Bilimsel süreç becerileri & 3 & $\begin{array}{l}\text { Ö3: Fen bilimlerine dair bir problemi çözme deyince bilim- } \\
\text { sel süreç becerileri aklıma geliyor. }\end{array}$ \\
\hline Deney yapma & 9 & $\begin{array}{l}\text { Ö4: Fen derslerinde beceri özellikle deney yaparken daha } \\
\text { da fazla ortaya çıkıyor. }\end{array}$ \\
\hline Proje tabanlı etkinlikler & 2 & $\begin{array}{l}\text { Ö6: Fen bilgisi dersinde becerisi olan bir öğrenci verilen } \\
\text { proje ödevlerinde daha yaratıcı ve bundan dolayı da daha } \\
\text { başarılı oluyor. }\end{array}$ \\
\hline Drama, rol yaptırma & 3 & \\
\hline Klasik yöntem & 6 & $\begin{array}{l}\text { Ö5: Öğretmen merkezli ve düz anlatım yapmak duru- } \\
\text { munda kalıyoruz. }\end{array}$ \\
\hline
\end{tabular}

*görüş sıklığının öğretmen sayısından fazla olmasının sebebi bir öğretmenin birden fazla görüş belirtmesidir.

Fen bilimleri öğretmenlerinden disiplinleri gereği becerileri işe koşan süreçlerin olduğu etkinlikler beklenmektedir. Öğretmenlerin mesleki olarak beri odaklı etkinlik gerçekleştirme durumlarını ortaya çıkarmak amacıyla yöneltilen görüşme sorusuna; dokuz görüşte deney yapma, altı görüşte klasik yöntemleri işe koşma, dört görüşte günlük hata odaklı etkinlikler gerçekleştirme cevapları verilmiştir. Öğretmenler aynı anda birden fazla etkinlik süreçlerini işe koştuklarını da belirtmişlerdir (tablo 5). Ayrıca öğretmen; farklı etkinlik uyguladıklarında öğrencilerin becerilerinin de geliştiğini savunmaktadır. Örneğin bir öğretmen; "Ö2: Çeşitli etkinlikler kullanarak öğrencilerimin becerilerini geliştirmeye çalısıyorum. Istasyon yaratıcılılarını kullanabilecekleri şekilde etkinlikler de kullanabiliyorum, oyunlaştırarak, poster yaptırma , slogan bulma, bulmaca hazırlatma , deney tasarlama gibi." şeklinde görüş belirterek ders içi etkinliklerin fazla olduğunu vurgulamıştır.

Bir başka öğretmen; “Ö1: Fen Bilgisi dersi günlük hayatta karşılığı oldukça fazla olan bir derstir. Örneğin matematik kadar soyut değildir. Dolaysıyla Fen derslerini günlük hayata uyarlamak veya günlük hayattan tasarlamak kolaydır. Bu da yaparak yaşayarak öğrenme modeline veya gösterip yaptırma öğretim modeline dayanır. Bu öğretim modellerinde de kullanacağımız malzeme veya kavramlar günlük hayatta karşılığı olduğu için öğrencinin geçmiş tecrübeleri ve becerileri bu modellerle ders arasındaki ilişkiyi kavramakta kolaylık sağlar. Malum Fen demek deney demektir, gözlem demektir." görüşüyle temel becerilerin ve deneylerin fen derslerindeki önemine vurgu yapmıştır.

Derslerinde beceri deyince bilimsel süreç becerilerinin uygulandığını söyleyen bir öğretmenin görüşü şu şekildedir: “Ö3: Bilimsel süreç becerileri aklıma geliyor. Fen bilimlerine dair bir problemi 
öğrencinin bilim adamı edasında süreç basamaklarını gerçekleştirerek bu problemi çözmeye çalışması fen bilimlerine dair bir etkinliktir. Deney malzemeleriyle amaca uygun bir deney yapabilmesidir."

Fen bilimleri derslerinde beceri geliştirmeye dair etkinlikler ile ilgili öğretmenler şu şekilde görüş belirtmiştir: "Ö9: Fen bilgisi dersinde grup halinde yapılan etkinlikler öğrencilerin sosyal olmalarını sağlayarak iletişim becerilerini geliştirir.

Ö10: Rol yaptırma, deney uygulamaları, grup halinde yapılan etkinlikler, projeler fen derslerinde beceri geliştirmeye yöneliktir.

Ö14: Beceriyi ortaya koymak adına onlara deney yaptırmamı gerekiyor. Onlara gözlem, sınıflandırma, veri toplama, tahmin, yorumlama, çıkarım yaptırmamı gerekiyor."

Bir öğretmen beceri geliştirmede okul dışı öğrenme ortamlarının etkisini şu şekilde belirtmiştir: "Ö10: Bilim şenliği, Kan alma, Kan grubunu tespit etme, Çevreye daha duyarlı olma, Güneş enerjisinden yemek pişirme, 'Bilim sanat merkezi' gezisi yaptığım etkinlikler."

\subsection{Programda yer alan beceri kavramlarına ait görüşler (Soru 3):}

Tablo 6. Fen bilimleri dersi öğretim programında yer alan beceri alanı ile ilgili görüşler

\begin{tabular}{lrl}
\hline \hline Görüşler & $f^{*}$ & Örnek \\
\hline Beceri öğrenme alanı hakkında bilgisi var & 3 & $\begin{array}{l}\text { Ö12: Fen bilgisi dersi kapsamında oyun } \\
\text { hamurları kullanarak model yapımı gibi } \\
\text { etkinlikler, deneyler BSB için uygundur. }\end{array}$ \\
Beceri öğrenme alanı hakkında bilgisi yok & $12 \begin{array}{l}\text { Ö1: Açıçası fen bilimleri dersi öğretim } \\
\text { programında yer alan beceri öğrenme } \\
\text { alanı ile ilgili bir bilgive sahip değilim }\end{array}$ \\
\hline
\end{tabular}

Tablo 6'ya göre öğretmenlerin üç tanesi yürütmekte oldukları fen bilimleri dersi öğretim programında yer alan beceri öğrenme alanı ile ilgili bilgi sahibi iken, on iki öğretmen bu alan hakkında bilgi sahibi olmadıklarını belirtmiştir. Hatta bazı öğretmenler böyle bir alanın kesinlikle olmadığı hakkında görüş belirtmiştir. Beceri öğrenme alanının öğretim programında yer alıp almadığı hakkında fikir sahibi olmayan bir öğretmen şu şekilde görüş belirtmiştir: "Ö1: Açıç̧ası fen bilimleri dersi öğretim programında yer alan beceri öğrenme alanı ile ilgili bir bilgiye sahip değilim... Yani programda ayrıca belirtilmez o bölüm, kazanımlar arasında zaman zaman bahse konu olur."

Beceri öğrenme alanının öğretim programında yer almadığını söyleyen bir öğretmen şu şekilde görüş belirtmiştir: "Ö14: Fen bilgisi dersi öğretim programında BSB (Bilimsel Süreç Becerileri) öğrenme alanı yok."

“Ö15: Fen bilgisi dersi öğretim programı sürekli değişiyor ve programı takip edemiyoruz. Bu yüzden bu alan yeni getirilmiş olabilir. Bizlere bu konu ile ilgili eğitim verilmeli." şeklinde görüş belirten bir öğretmen program değişikliklerinde öğretmenlerin bilgilendirilmediğini savunmaktadır. 
Fen bilimleri dersi öğretim programında beceri öğrenme alanı ile ilgili fikir sahibi öğretmenler şu şekilde görüş belirtmiştir: "Ö12: Fen bilgisi dersi kapsamında oyun hamurları kullanarak model yapımı gibi etkinlikler, deneyler BSB (Bilimsel Süreç Becerileri) için uygundur.

Ö13: Fen bilgisi ders programı kapsamında doğa gezileri, mikroskop kullanımı ile yapılan gözlemler, el becerilerini kullandıkları deneyler ve etkinlikler BSB (Bilimsel Süreç Becerileri) destekliyor."

\subsection{Beceri, yetenek ve zekâ kavramları hakkındaki görüşlere ait bulgular (Soru 3):}

Tablo 7. Beceri, yetenek ve zekâ ilişkisine yönelik görüşler

\begin{tabular}{lrl}
\hline \hline Görüşler & $f$ & Örnek \\
\hline $\begin{array}{l}\text { Beceri, zeka ve yetenek ilişkili- } \\
\text { dir. }\end{array}$ & $11 \begin{array}{l}\text { Ö6: Beceri yetenek zeka arasında ilişki vardır. } \\
\text { Bence yetenekleri zekâ belirler ve böylece bu } \\
\text { alanda beceri kazanılır. }\end{array}$ \\
Beceri, zeka ve yetenek aynıdır. & 3 & $\begin{array}{l}\text { Ö7: Zekâ, yetenek ve beceri hemen hemen aynı } \\
\text { kavramlardır }\end{array}$ \\
Fikir yok. & 1 & -
\end{tabular}

Günlük hayatta sıklıkla birbiri yerine kullanılan beceri, zekâ ve yetenek kavramlarının fen bilimleri öğretmenleri tarafından algılanma durumları şu şekildedir: Tablo 7'de de görüldüğü üzere 11 öğretmen zekâ, beceri ve yeteneğin birbiri ile ilişkisi olduğunu belirtirken, üç öğretmen ise bu üç kavramının birbirisinin aynı olduğunu belirtmişlerdir. Bir öğretmen de konu hakkında herhangi bir fikir beyan etmemiştir. Zeka, beceri ve yetenek kavramları arasındaki ilişkilere ait bazı öğretmen görüşleri aşağıda belirtilmiştir:

Ö1: "Tecrübelerimden faydalanarak zekası yüksek bir öğrencinin genelde beceri ve yeteneklerinin de iyi olduğunu gözlemledim. Demek istediğim; lyi bir zekaya sahip olan öğrenci beceri ve yeteneklerini daha çok geliştirebildiği veya var olan yeteneklerini kullanmada etkin yollar bularak daha iyi yansıttığını düşünüyorum. Fakat, bazen çok zeki olamayan ama yeteneği olan bir öğrenci yeteri kadar tecrübe edinmediği için (becerisini geliştirmediği için) bu yeteneğini fark ettirememekte veya hakkını verememektedir. Dolaysıyla beceri, yetenek ve zekâ kavramları birbirini pozitif yönde etkileyen ilişkili kavramlardır." görüşüne sahip öğretmenimiz üç kavramın yakın ilişkisinden tecrübelerinden yola çıkarak bahsetmiştir. Bu üç kavramın tecrübelerden de kaynaklandığını belirtmiştir.

Ö3: "Zekâyı tanımlayacak olursam kişinin doğuştan sahip olduğu ve bunun yaşantı deneyim ile geliştirilebildiği bir birleşimdir. Zekâ zihinsel becerilerde etkin rol oynar. Yetenek ise kişinin doğuştan getirdiği psikomotor, sözel, sayısal (zihinsel) becerilerdir. Beceri yetenek ve zekâ arasında ilişki vardır. Zekâ ve yetenek birleşimi beceriyi oluşturur." görüşüne sahip öğretmen zeka ve yeteneğin birleşiminden becerinin ortaya çıktığını belirtmiş̧ir. 
Yukarıda kıdem yılı az mesleki tecrübesi yeni iki öğretmenin görüşleri yer almıştır. Aşağıda kıdem yılı daha fazla öğretmen görüşlerine yer verilmiştir:

Ö12: "Bir öğrencinin yetenekleri doğuştan gelir. Zekâ ise geliştirilebilir. Ancak beceri var olan zeka ile yeteneklerini birlikte kullanabiliyorsa ortaya çıkar."

Ö14: "Zekâ matematiksel, sözel, görsel, bedensel ve kinestetik türde olabilir. Eğer bir öğrenci resim çizebiliyor ise yeteneklidir ve bu aynı zamanda görsel zekâya da sahip olduğunu gösterir. Ancak fen bilgisi dersinde bu yeteneğini kullanabiliyor olması bir beceri ister."

\section{6. Öğretmenlerin becerilerin ölçmesi hakkındaki görüşlerine ait bulgular (Soru 6):}

Tablo 8. Becerilerin ölçülmesine dair görüşler

\begin{tabular}{lcl}
\hline \hline Görüşler & $f$ & Örnek \\
\hline Beceri odaklı & 3 & $\begin{array}{l}\text { Ö5: Şu an kazanım ağırlıklı̈llçüyorlar. } \\
\text { ölçme }\end{array}$ \\
$\begin{array}{l}\text { Bilgi odaklı ölçme } \\
\text { Fikrim Yok }\end{array}$ & 8 & $\begin{array}{l}\text { Ö9: TEOG sorularının bilgiyi ölçmeye yönelik olduğunu düşünüyo- } \\
\text { rum. }\end{array}$ \\
\hline
\end{tabular}

Tablo 8'de görüldüğü üzere; öğretmenlerin üç tanesi ülke genelinde uygulanan sınavlarda -ortaokul öğretmeni olmaları sebebiyle TEOG (Temel Eğitimden Ortaöğretime Geçiş Sınavı) sınavlarında- beceri odaklı ölçme gerçekleştirildiğini, sekiz öğretmen ise bilgi odaklı gerçekleştirildiğini belirtmişlerdir. Dört öğretmen de konu ile ilgili bir görüş belirtmemiştir. Görüş belirtmeyen öğretmenler genellikle TEOG'a girecek olan sınıflarda ders yürütmemektedir.

Bilgi odaklı ölçmelerin gerçekleştiğini savunan bir öğretmen şu şekilde görüş belirtmiştir: "Ö6: TEOG ezbere dayalı bir sistem. Konu alanı öğrenciler için çok fazla. Ve sadece son sınıftaki konulardan soru gelmesi de ikinci bir sorun. Çok da beceriye dayalı sorular geldiği söylenemez. Örneğin; bir kaldırma kuvveti konusundan 12 soru gelebiliyor. Aynı soru kalıbını tekrar tekrar sorabiliyorlar. Bu da yine ezbere dayalı sisteme vurgu yapıyor." Sınavların beceri odaklı olduğunu belirten öğretmen görüşü de şu şekildedir: "Ö2: Bence TEOG soruları öğrencilerin sadece bilişsel becerilerini ölçüyor. Bilişsel anlamda anlama, karşılaştırma yapma, çıkarımda bulunabilme gibi becerileri sınanıyor."

TEOG sınavında beceri odaklı soruların yer aldığını belirten öğretmenler şu şekilde görüş belirtmiştir: "Ö5: Şu an kazanım ağırıklı̈lçüyorlar, sorularda (geçen sene girdim) mesela kaldırma kuvveti formülize şekilde vermiyoruz da batan kısmı öz kütleye bağlı değildir gibi ... Sıvılar bu şekilde geliyor. Mesela iki kap koyuyorlar resimde birisine zeytinyağı birisine su diyor. Farklı oranlarda battı sebebi ne olabilir. Aslında zaten çıkarım yapabilmeyi ölçüyor sorularda, uygun artık eskisine göre beğeniyorum ben. Hipotezi ne olabilir gibi sorular soruluyor." 
Ersin KARADEMIR | Emine SARIKAHYA | Kübra ALTUNSOY

\section{7. Öğretmenlerin becerinin ölçülmesi konusundaki görüşlerine ait bulgular:}

Tablo 9. Becerilerin ölçülebilirliğine dair görüşler

\begin{tabular}{lll}
\hline \hline Görüşler & $f$ & Örnek \\
\hline Beceri ölçülebilir & 7 & $\begin{array}{l}\text { Ö13: Beceri testler, ev ödevleri, yapılan materyallerin değerlendi- } \\
\text { rilmesi ve akran değerlendirilmesi ile ölçülebilir. }\end{array}$ \\
Beceri ölçülemez & 6 & Ö4: Beceri bence ölçülemez. Objektif bir ölçüm yapılamaz. \\
Fikir yok & 2 & -
\end{tabular}

Tablo 9'da görüldüğü üzere; öğretmenlerin becerilerin ölçülebilirliğine dair görüşlerine göre; yedi öğretmen (Ö1, Ö2, Ö3, Ö5, Ö6, Ö9 ve Ö13) becerinin testler, ödevler, rubrikler, deneyler vb. yollarla ölçülebileceğini belirtirken, altı öğretmen (Ö4, Ö7, Ö8, Ö10, Ö14 ve Ö15) becerinin hiçbir şekilde ölçülemeyeceğini görüş olarak bildirmişlerdir. İki öğretmen ise görüş belirtmemiştir. Kıdemi düşük öğretmenlerin çoğu becerilerin ölçülebileceği hakkında görüş belirtmişlerdir. Becerilerin ölçülebilirliğine dair bir öğretmen şu şekilde görüş belirtmiştir: "Ö2: Beceriler dolaylı yoldan ölçülebilir. Konu ile ilgili derecelendirilmiş rubrik kullanarak, ilgili kazanımın ne derecede yapıldığı ölçülebilir." Bazı öğretmenler ise becerilerin ölçülemeyeceği hakkında görüş belirtmişlerdir: "Ö8: Beceriyi ölçmemiz çok zor. Bunu ölçmek adına kazanımlarımız yok." Bazı öğretmenler ise becerinin farklı yollardan ölçülebileceğini şu şekilde belirtmişlerdir: “Ö6: Beceri, tek bir ölçekle ölçülemez bence. Bir soru önce bahsettiğim gibi, her öğrencinin kendini gösterebildiği beceri farklı oluyor. $O$ yüzden her öğrencimi bir faaliyette kullanmaya çalışıyorum, sözlü notlarını buna göre veriyorum. Sınavlarımda da doğruyanlış bölümleri, testler, klasik sorular, şekilli yorum soruları gibi ölçeklerle yelpazeyi genişletmeye çalışıorum."

\section{Tartışma, Sonuç ve Öneriler}

\subsection{Tartışma ve Sonuç}

Öğretmenler beceri kavramı ve sınıflandırması hakkında farklı görüşler ortaya çıkarmışlardır. Öğretmenler becerileri üst düzey düşünme, çoklu zeka (zeka alanlarına göre), görsel-elsel vb. olarak, bilişsel,-duyuşsal- psikomotor beceriler olarak sınıflandırmışlardır. Fakat hiçbir öğretmen -kıdem yılı az veya fazla- beceri sınıflandırmasını fen bilimleri dersi öğretim programı bağlamında yapmamıştır. $\mathrm{Bu}$, beceri kavramının disiplinlere göre farklılıklar içermesinden kaynaklanmaktadır. Örneğin Türkçe alanında beceri deyince; okuma, yazma, konuşma ve dinleme becerileri anlaşıırken, günlük hayatta el becerisi kavramı öne çıkmaktadır. Ayrıca günümüzde üst düzey düşünme becerileri, 21. yüzyıl becerileri vb. kavramlar ortaya çıkmış ve beceri kavramı bu sebeple çeşitlilik göstermiş̧ir. Bilimsel süreç becerileri ile ilgili Korucuoğlu (2008) yaptığı çalışmada öğretmen adaylarında buna benzer farklılaşmaların olduğunu saptamıştır.

Bu çalışmada fen bilimleri öğretmenlerinin beceri kavramı hakkında yeterli düzeyde bilgi sahibi olmadığı ortaya çıkmıştır. Fen bilimleri öğretmenlerinin yalnızca üç tanesi öğretim programında yer 
alan beceri öğrenme alanı hakkında bilgi sahibidir. Kıdem yılı az olan öğretmenlerden de dahil olmak üzere çoğu öğretmen programda yer alan ve Milli Eğitim Bakanlı̆ınca yayınlanan beceri öğrenme alanını bilmemektedirler. Yapılan birçok çalışma benzer sonuçlar içermektedir (Türkmen \& Kandemir, 2012; Şimşek, 2010; Karslı, Şahin ve Ayas, 2009; Farsakoğlu ve diğerleri, 2008; Burke, 1996; Dowling \& Filer, 1999). Bazı öğretmenler bu konuda eğitim alınabileceği görüşünü aktarmışlardır.

Becerilerin ölçülmesi konusunda öğretmenlerin bir kısmı ölçülemeyeceği şeklinde görüş belirtmiştir. Bu görüşe yakın sayıda öğretmen de ölçülebilirliği hakkında fikir beyan etmiştir. Ulusal sınavlarda özellikle ortaokul sekizinci sınıfta gerçekleştirilen TEOG (Temel Eğitimden Ortaöğretime Geçiş) sınavında beceri odaklı soruların olmadığını daha çok bilgi düzeyinde soruların yer aldığı sonucuna varmışlardır. Ayrıca kendi gerçekleştirdikleri ölçme-değerlendirme faaliyetlerinde de becerilere yönelik değil bilgi düzeyinde sorular hazırladıklarını belirtmişlerdir.

Derslerinde beceri odaklı etkinlik süreçlerini şu şekilde belirtmişlerdir: günlük hayat bağlamlı, bilimsel süreç becerileri temelli, deney yapma, proje tabanlı etkinlikler, drama, rol yaptırma, klasik yöntem ile ders süreçlerini yürüttüklerini belirtmişlerdir. Dersi zenginleştirmek adına yaptıkları etkinliklerin beceri bağlamlı oldukları hakkında fikir sahibi değillerdir. Coşgun-Bergen (2012), Türkmen vd. (2006) ve Demirtaş (2006) de benzer sonuçları ortaya koymuşlardır.

\section{2. Öneriler}

- Fen bilimleri öğretim programında yer almasına rağmen öğretmenler bu öğrenme alanı ile ilgili görüş belirtmemektedirler. Kıdem yılı her ne olursa olsun öğretmenler beceri konusunda mutlaka bilgilendirilmelidirler.

- Öğretmenlere beceri odaklı etkinliklerin hazırlanması, uygulanması ve değerlendirilmesi ile ilgili hizmet içi eğitimler verilmelidir.

- Fen bilimlerinde, ders ve öğretmen kitaplarında becerilere daha fazla vurgu yapılmalıdır. Ayrıca kazanım ve etkinlikler becerilerle mutlaka ilişkilendirilmelidir.

- Derslerin zenginleştirilmesi için beceri odaklı materyaller işe koşulmalı ve öğretmenler bu hususta sürece dahil edilmelidir.

- Becerilerin ölçülmesi konusunda ölçme-değerlendirme-soru hazırlama faaliyetleri gerçekleştirilmelidir.

\section{Kaynaklar}

Aktamış, H. \& Şahin-Pekmez, E. (2011). Fen ve teknoloji dersine yönelik bilimsel süreç becerileri ölçeği geliştirme çalışması. Buca Eğitim Fakültesi Dergisi, 30, 199-205.

Bernstein, J. (2003). A recipe for inquiry. The Science Teacher, 9, 60-63.

Büyüköztürk, Ş., Kılıç Çakmak, E., Akgün, Ö.E., Karadeniz, Ş. ve Demirel, F. (2008). Bilimsel araştırma yöntemleri (14. Baskı). Ankara: Pegem Yayınları 
Büyüköztürk, Ş., Kılıç Çakmak, E., Akgün, Ö.E., Karadeniz, Ş. ve Demirel, F. (2014). Bilimsel araştırma yöntemleri (17. Baskı). Ankara: Pegem Yayınları

Bozkurt, O. (2005). Ilköğretim 6. sınıf fen bilgisi dersinin Dunn ve Dunn öğrenme stili modeli kullanılarak öğretilmesinin öğrencilerin akademik başarı, tutum ve bilimsel süreç becerileri üzerine etkisi. Yayınlanmamış Doktora Tezi, Gazi Üniversitesi, Ankara.

Burke, S. A. (1996). Teacher preferences for teaching problem solving and science process skills. Yüksek Lisans Tezi. Texas Woman's University, United States.

Chin, C. (2003). Success with investigations. The Science Teacher, 2, 34-40.

Coşgun-Bergen, E. (2012). Illköğretim II. kademe fen ve teknoloji öğretmenlerinin bilimsel süreç becerileri ile ilgili bilgi, farkındalık ve kullanma düzeylerinin araştırılması (Tokat örneği), Yayınlanmamış Yüksek Lisans Tezi, Gaziosmanpaşa Üniversitesi, Fen Bilimleri Enstitüsü, Tokat.

Creswell, J. W. (2007). Qualitative inquiry \& research design choosing among five approaches. Sage Publications.

Çepni, S. (2010). Araştırma ve proje çalışmalarına giriş. Trabzon: Akademi Kitabevi.

Demirtaş, Z. (2006). Öğrencilerin bilişsel gelişim düzeyleri ve bilimsel gelişim yeteneklerin göre ÖsS başarılarının incelenmesi. XV. Ulusal Egitim Bilimleri Kongresi, 13-15 Eylül 2006, Muğla Üniversitesi: Muğla.

Downing, J. E. \& Filer J. D. (1999). Science process skills and attitudes of preservice elementary teachers. Journal of Elementary Science Education, 11(2), 57-64.

Erdoğan, M. N. (2005). Illköğretim 7. sınıf öğrencilerinin atomun yapısı konusundaki başarılarına, kavramsal değişimlerine, bilimsel süreç becerilerine ve fene karsı tutumlarına sorgulayıcıaraştırma (inqury) yönteminin etkisi. Yayınlanmamış Yüksek Lisans Tezi, Gazi Üniversitesi, Ankara.

Farsakoğlu, Ö. F. , Şahin. Ç. , Karslı, F. , Akpınar, M. \& Ültay, N. (2008). A study on awareness levels on prospective science teachers on science process skills in science education. World Applied Sciences Journal, 4(2), 174-182.

Finnish National Board of Education (2004). National core curriculum for basic education 2004. Vamlla: Vammalan Kirjapaino Oy.

Harlen, W. (1999). Purposes and procedures for assessing science process skills. Assessment in Education, 6(1), 129-140. 
Joseph, C. (1998). A study of process outcomes in physics in relation to some select cognitive, affective, social and environmental variables (An Unpublished Ph.D. Thesis) Mahatma Gandhi University. In Sixth Survey of Research in Education.

Jimarez, T. (2005). Does alignment of constructivist teaching, curriculum, and assessment strategies promote meaningful learning? Ph.D. dissertation, New Mexico State University, United States. ProQuest Digital Dissertations Database, (Publication No. AAT 3208658), 15.01.2008.

Kanlı, U. (2007). 7E modeli merkezli laboratuvar yaklaşımı ile doğrulama laboratuvar yaklaşımlarının öğrencilerin bilimsel süreç becerilerinin gelişimine ve kavramsal başarılarına etkisi. Yayınlanmamış Doktora Tezi, Gazi Üniversitesi Eğitim Bilimleri Enstitüsü, Ankara.

Karsl,, F., Şahin, Ç. \& Ayas, A. (2009). Determining science teachers' ideas about the science process skills: A case study. Procedia Social and Behavioral Sciences,8, 890-895.

Korean Ministry of Education, Science and Technology (2008). The school curriculum of the republic

Korea.http://www.english.go.kr/ebs/DownloadFile.laf?file=/ebse/comnboard/data/938/ National +School+Curriculum-English(2008).pdf adresinden erişilmiştir.

Korucuoğlu, P. (2008). Fizik öğretmen adaylarının bilimsel süreç becerilerini kullanım düzeylerinin fizik tutumu, cinsiyet, sınıf düzeni ve mezun oldukları lise türü ile ilişkilerinin değerlendirilmesi.

Yayımlanmamış Yüksek Lisans Tezi, Dokuz Eylül Üniversitesi Eğitim Bilimleri Enstitüsü, İzmir.

Kurz, J. S. (2001). Open-ended inquiry. The Science Teacher, 68(1), 62-67.

K.K.T.C. Milli Eğitim ve Kültür Bakanlığı (KKTCMEB). (2005). Kıbrıs Türk Eğitim Sistemi Yeni Program Yaklaşımları. Lefkoşa

K.K.T.C. Milli Eğitim ve Kültür Bakanlığı (KKTC MEB). (2009). “illkokul (temel eğitim ı. kademe) sosyal bilgiler dersi öğretim programı (4.5. Sınıflar).

Miles, M. B., \& Huberman, A. M. (1994). An expanded sourcebook qualitative data analysis. London: Sage.

M.E.B. (2013). ilköğretim kurumları (ilkokullar ve ortaokullar) fen bilimleri dersi (3, 4, 5, 6, 7 ve 8. sınıflar) öğretim programı. 11.08.2016 tarihinde http://ttkb.meb.gov.tr adresinden erişilmiştir.

M.E.B.(2006). Illkoğretim fen ve teknoloji dersi (4. ve 5. sınıflar ) öğretim programı 11.08.2016 tarihinde http://ttkb.meb.gov.tr adresinden erişilmiştir.

Ministry of Education, Singapore (2007). Science syllabus primary. Singapore: Curriculum Planning \& Development Division. 
Özet, í. (2014). Kent araştırmaları ve nitel yöntem. Yayınlanmamış Yüksek Lisans Tezi, Süleyman Demirel Üniversitesi Sosyal Bilimler Enstitüsü, Isparta.

Öztuna-Kaplan, A. (2013). Durum çalışması. S. Baştürk (Ed.). Bilimsel araştırma yöntemleri lçinde (197- 217). Ankara: Vize Yayıncilı.

Pardhan, H. (2000). Science activities and ideas: Experiencing science process skills. Imperial Oil National Centre for Math, Science and Technology Education, Alberta.

Semerci, N. \& Yanpar Yelken, T. (2010). illköğretim programlarındaki ortak temel becerilere ilişkin öğretmen görüşleri (Elazığ ili örneği). Doğu Anadolu Bölgesi Araştırmaları, 8(2), 47-54.

Şimsek, L., C., (2010). Sınıf öğretmeni adaylarının fen ve teknoloji ders kitaplarındaki deneyleri bilimsel süreç becerileri acısından analiz edebilme yeterlilikleri. IIlköğretim Online, 9(2), 433-445.

Tatar, N. (2006). Illköğretim fen eğitiminde araştırmaya dayalı öğrenme yaklaşımının bilimsel süreç becerilerine, akademik basarıya ve tutuma etkisi, Yayınlanmamış Doktora Tezi, Gazi Üniversitesi Eğitim Bilimleri Enstitüsü, Ankara.

Timmons, M. (2003). Inquiring minds. The Science Teacher, 10.

The Courses of Study in Japan (2004). Japanese Research Team for U.S.-Japan Comparative Research on Science Mathematics and Technology Education.

Türkmen, H. \& Kandemir, E. M. (2011). Öğretmenlerin bilimsel süreç becerileri öğrenme alanı algıları üzerine bir durum çalışması. Journal of European Education, 1(1), 15-24.

Türkmen, L., Ercan, S. ve Süren, T. (2006) . Son sınıf düzeyinde ve farklı alanlarda öğrenim gören öğretmen adaylarının bilimsel işlem beceri düzeyleri. XV. Ulusal Eğitim Bilimleri Kongresi, 13-15 Eylül 2006, Muğla Üniversitesi: Muğla.

Türkmen, L. (2006). Farklı alanlardaki öğretmen adayların bilimsel işlem beceri düzeyleri. VII. Ulusal Fen Bilimleri ve Matematik Egitimi Kongresi, 7-9 Eylül 2006, Gazi Üniversitesi: Ankara.

Yayla, G. \& Hançer, H. (2011). Fen bilgisi öğretim programında yer alan bilimsel süreç becerileri (bsb) kazanımlarına yönelik öğretmenler tarafından yapılan çalışmaların incelenmesi. 2nd International Conference on New Trends in Education and Their Implications 27-29 April, 2011 Antalya-Turkey

Yıldırım, A. ve Şimşek, H. (2005). Sosyal bilimlerde nitel araştırma yöntemleri. (5. Baskı). Ankara: Seçkin Yayıncllık.

Yıldırım, A., \& Şimşek, H. (2008). Sosyal bilimlerde araştırma yöntemleri. Ankara: Seçkin Yayıncılık. 


\section{Ek.1: Görüşme Soruları}

1) Beceri kavramı hakkında neler düşünüyorsunuz? Beceriyi tanımlayınız.

2) Fen bilgisi derslerinizde beceri denildiğinde anladığınız aktivite ve etkinlikler nelerdir? Biraz açıklayabilir misiniz?

3) Beceri, yetenek ve zeka kavramları hakkında neler düşünüyorsunuz. Sizce bu kavramlar arasında ilişki var mıdır? Varsa ne olabilir?

4) Fen bilimleri dersi öğretim programında yer alan beceri öğrenme alanı ile ilgili ne düşünüyorsunuz. Bu alan kapsamında yaptığınız ders çalışmaları/ etkinlikler nelerdir?

5) Beceriler nasıl sınıflandıııır? Siz becerileri nasıl sınıflandıırsınız? Öğretim programında bu becerileri nasıl konumlandırırsınız?

6) Sizce ulusal sınavlarda yönelik beceri geliştirme ile ilgili sorular var mı? Beceriye yönelik sorular olmalı mı?

7) Fen bilgisi dersinde beceri geliştirmek için çalışmalar yapıyor musunuz? Yaptığınız çalışmalar nelerdir? Ders içi uygulamalarınızda klasik yöntemlerin dışında kullandığınız alternatif uygulamalar nelerdir?

8) Beceri ölçülebilir mi? Eğer ölçülebilirse nasıl ölçülür? Siz ölçmek için neler yapıyorsunuz? 